\title{
Effectiveness of minimally invasive surgical procedures in the acceleration of tooth movement: a systematic review and meta- analysis
}

\author{
Alaa M. H. Alfawal', Mohammad Y. Hajeer ${ }^{1 *}$ D, Mowaffak A. Ajaj ${ }^{1}$, Omar Hamadah $^{2}$ and Bassel Brad ${ }^{3}$
}

\begin{abstract}
Objective: The objective of this study was to assess systematically the available scientific evidence relating the efficiency of minimally invasive surgical procedures in accelerating orthodontic tooth movement and the adverse effects associated with these procedures.

Methods: Electronic search of these databases CENTRAL, EMBASE, Scopus, PubMed, Web of Science, Google Scholar Beta, Trip, OpenGrey and PQDT OPEN was performed (last updated January 2016). The reference lists of the included studies were hand searched. Unpublished literature and ongoing studies were also checked electronically through ClinicalTrials.gov and (ICTRP). Randomized controlled trials (RCTs) with patients who received minimally invasive surgical procedures combined with fixed orthodontic appliances compared with conventional treatment were included. Cochrane's risk of bias tool was used to assess risk of bias.

Results: Four RCTs (61 patients) and nine ongoing protocols were included in this review. Only three RCTs were suitable for quantitative synthesis. Higher tooth movement rate was found with the minimally invasive surgical procedures by a weighted mean difference of $0.65 \mathrm{~mm}$ for 1 month of canine retraction (WMD $=0.65: 95 \% \mathrm{Cl}$ $(0.54,0.76), p<0.001)$ and by a weighted mean difference $1.41 \mathrm{~mm}$ for 2 months (WMD $=1.41: 95 \% \mathrm{Cl}(0.81,2.01)$, $p<0.001)$. No adverse effects associated with these procedures were reported.

Conclusions: There is limited available evidence about the effectiveness of minimally invasive surgically accelerated orthodontics (MISAO). Although the current review indicated that MISAO can help in accelerating canine retraction, further research in this domain should be performed before it can be recommended in everyday clinical practice.
\end{abstract}

Keywords: Orthodontics, Accelerated tooth movement, Minimally invasive, Surgical, Flapless, Corticotomy

\section{Review}

Background

Comprehensive orthodontic treatment usually lasts for more than 1 year and a half when fixed appliances are used to treat moderate to severe cases of malocclusion [1], with a significant difference which can be affected by various factors $[2,3]$. Increased orthodontic treatment duration has several adverse effects like pain, discomfort, caries, gingival recession and apical root

\footnotetext{
* Correspondence: myhajeer@gmail.com

'Orthodontics Department, University of Damascus Dental School,

Damascus, Syria

Full list of author information is available at the end of the article
}

resorption $[4,5]$. Moreover, most adult patients want to finish their treatment at the earliest opportunity due to social and aesthetic concerns [6]. Therefore, both orthodontists and patients are interested in procedures that can accelerate tooth movement [7].

Recently, various methods have been suggested to reduce orthodontic treatment time such as adequate use of brackets, controlling force levels and relying on less friction bracket systems [8], photobiomodulation [9], pharmacological approaches [10] and low-intensity laser irradiation [11]. However, the most clinically applied and most examined with the potential of significantly decreasing treatment time are the surgical 
procedures [12]. Over the past, several forms of corticotomy has been used to reduce orthodontic treatment time $[13,14]$. The acceleratory impact of corticotomies was attributed primarily to the so-called regional accelerated phenomena (RAP) [13, 15]. Furthermore, corticotomies may stimulate the expression of inflammatory markers and cytokines which leading to increased osteoclast activity [16-19].

Although corticotomy techniques have been effective in inducing rapid tooth movement [20-22], they were relatively invasive requiring full mucoperiosteal flaps, suturing in conjunction with the associated surgical risks such as pain, swelling [23], slight interdental bone and attached gingiva loss [24]. This may explain the lack of their common spread among orthodontists in their daily practice. So as a result, more conservative flapless corticotomy techniques have been proposed in the last years, such as corticision [25], piezocision [26-28], microosteoperforations (MOPs) [17, 29], and laser-assisted flapless corticotomy [30, 31].

It has been claimed that orthodontic treatment advances faster with negligible danger of side effects after minimally invasive surgical procedures, but there is a lack of the evidence related to the effectiveness of minimally invasive surgical procedures in accelerating tooth movement. Thus, the aim of this review is the critical and systematic appraisal of the available evidence regarding the effectiveness of minimally invasive surgical procedures in inducing rapid orthodontic tooth movement and the untoward effects of these surgical interventions.

\section{Materials and methods}

Primarily, a PubMed pilot search was performed, and then, two potentially eligible trials were assessed before writing the protocol. Registration with PROSPERO was performed during the first stages of this review (http:// www.crd.york.ac.uk/PROSPERO/display_record.asp?ID= CRD42016036737; 2016: CRD42016036737). This systematic review was written according to the Cochrane Handbook for Systematic Reviews of Interventions Version 5.1.0 [32] and the Preferred Reporting Items for Systematic Reviews and Meta-Analyses (PRISMA) guidelines [33, 34].

\section{Eligibility criteria}

Criteria of exclusion and inclusion were employed with reference to the Participants, Interventions, Comparisons, Outcomes and Study design (PICOS) framework. Study design: in vivo randomized controlled trials (RCTs) without any restrictions on publication year or language were included. Participants: healthy patients, both males and females with any age and type of malocclusion, of any ethnic group who received orthodontic treatment with fixed orthodontic appliances were included. Type of interventions: any sort of orthodontic treatment with fixed appliances (with/out the need to extract teeth in the context of treatment) assisted by minimally invasive surgical techniques for accelerating orthodontic tooth movement (i.e. corticision, piezocision, microosteoperforations, laser-assisted flapless corticotomy, interspetal bone reduction or any surgical procedure which is not required raising flap) were included. Comparisons: patients receiving conventional orthodontic treatment with fixed appliances (without any additional intervention to accelerate tooth movement). Outcomes: primary outcome: the rate of tooth movement (RTM) or any equivalent measurement that would give an idea about the efficacy of the non-invasive surgical procedure. Secondary outcomes: adverse side effects such as patientreported outcomes (pain, discomfort, oral-health-related quality of life, alteration in mastication, other experiences and satisfaction), or gingival and periodontal complications including (gingival recession, loss of attachment, depth of probing, bone resorption), or loss of anchorage and unwanted tooth movement (tipping, torquing, rotation) or iatrogenic harm to teeth (e.g., tooth vitality loss, root resorption) or stability of treatment in the long term.

\section{Search strategy}

Electronic search was performed in January 2016 with no time and language limitations in the following databases: The Cochrane Central Register of Controlled Trials (CENTRAL), EMBASE, Scopus, PubMed, Web of Science, Google Scholar Beta, Trip, OpenGrey (to identify the grey literature) and PQDT OPEN from proQuest (to identify dissertations and theses). Details of the electronic search strategy are provided in Additional file 1: Table S1. The reference lists of selected papers and relevant reviews were screened for any possible related studies which may have not been discovered by the electronic web-based search. ClinicalTrials.gov and World Health Organization International Clinical Trials Registry Platform Search Portal (ICTRP) were also checked electronically to retrieve any unpublished studies or currently accomplished research work (Additional file 2: Table S2).

\section{Study selection and data extraction}

Two reviewers (AMHA and MYH) assessed independently eligibility of the trials, and in case of disagreement, a third author (MAA) was asked to resolve this. The first check included only titles and abstracts. Full-text assessment was the second step for all papers appearing to be relevant and candidate for inclusion or when the title or abstract was vague to help in reaching an obvious judgement. Papers were excluded when they did not fulfil one or more of the inclusion criteria. Corresponding authors were e-mailed for obtaining clarifications or extra data. 
The same two authors (AMHA and MYH) conducted data extraction independently in the piloted and predefined data extraction tables. A third author $(\mathrm{OH})$ was consulted when there was a disagreement between the two authors to arrive at a resolution. The data extraction sheet included the following items: general information (the name of authors, the year of publication and study setting); methods (study design, treatment comparison); participants (sample size, age, gender); intervention (type of interventions, intervention site, technical aspects of interventions); orthodontic aspects (malocclusion characteristics, type of movement, appliance characteristics and biomechanics, frequency of orthodontic adjustments, follow-up time) and outcomes (primary and secondary outcomes mentioned, methods of outcome measurements, statistical significance of reported difference treated vs. controls).

\section{Assessment of risk of bias in included studies}

The quality of the included studies was evaluated by two reviewers (AMHA and MYH) using Cochrane's risk of bias tool [35]. When lack of consistency was observed, a third author (MAA) was consulted to arrive at a resolution.

We evaluated the following fields as at low, high or unclear risk of bias: sequence generation (selection bias), allocation concealment (selection bias), blinding of participants and personnel (performance bias), blinding of outcome assessors (detection bias), incomplete outcome data addressed (attrition bias), selective outcome reporting (reporting bias) and other bias.

The overall risk of bias of the included trials was assessed according to the following: low risk of bias: if all fields were evaluated as at low risk of bias (bias improbable to change the results critically), unclear risk of bias: if at least one or more fields were assessed as at unclear risk of bias (bias carries some doubt about the results) and high risk of bias: if at least one or more fields were evaluated as at high risk of bias (bias affect the results critically) (excluded from the primary analysis).

\section{Data synthesis and statistical analysis}

To evaluate the amount of heterogeneity of the included trials, the treatment interventions, treatment protocols, place of research, patients, methodology and outcome measures were assessed. From the statistical point of view, heterogeneity was first evaluated visually and then mathematically. Two reviewers (AMHA. and MYH.) checked the graphical display of the estimated treatment effects with $95 \%$ confidence intervals. The $I^{2}$ index was calculated to assess heterogeneity, and its values were interpreted as follows: low heterogeneity: 0 to $40 \%$, moderate to high heterogeneity: 30 to $60 \%$, significant heterogeneity: 50 to $90 \%$ and very significant heterogeneity: 75 to $100 \%$. Significant heterogeneity was also considered when $p$ values were less than 0.1 when applying $\chi^{2}$ tests [36]. Data was pooled to meta-analysis when trials had comparable interventions, subjects and outcomes. Mean differences (MD) with their associated $95 \%$ confidence intervals (CI) were chosen to express results as effect measure. The treatment effect was weighted (weighted mean difference ( WMD)) using calculations based on a random effects model.

This model was deemed suitable because of the observed differences in settings and populations. The inverse-variance method was chosen in cases of splitmouth design, and the standard deviation (SD) of the difference was calculated according to this formula:

$$
\sqrt{\mathrm{Sd} 1^{2}+\mathrm{Sd} 2^{2}-2 \times r \times \mathrm{Sd} 1 \times \mathrm{Sd} 2}
$$

where $\mathrm{Sd} 1$ and $\mathrm{Sd} 2$ are the standard deviations between quadrants, respectively, and $r$ is the correlation coefficient between quadrants. We deemed $r=0.5$ for split-mouth designs and $r=1$ for parallel designs. Then, the standard error (SE) was calculated: $\mathrm{SE}=\mathrm{SD} / \sqrt{ }(n)$. Meta-analyses were undertaken in (Review Manager (RevMan), Version 5.3. Copenhagen: The Nordic Cochrane Centre, the Cochrane Collaboration, 2014).

In a future update of this review, if an appropriate number of papers (i.e. more than 10 papers) evaluated identical interventions and they have been included in a meta-analysis, publication bias will be evaluated using standard funnel plots. In addition, subgroup analyses based on the type of interventions (piezocision, microosteoperforations, interseptal bone reduction, corticision, lasercision) and age stage (adolescents, adults) will be done. Subgroup analysis is important especially when there is considerable heterogeneity.

If an adequate number of trials are included in future updates, the vigour of the results will be evaluated using sensitivity analyses. This will include repeating the analyses after eliminating high-risk bias trials or studies with high chance of heterogeneity involving dominant effects of large studies and the variation in outcomes related to the scenario of orthodontic treatment (extraction, nonextraction), or type of minimally invasive surgery (piezocision, micro-osteoperforations, interseptal bone reduction), or age stage (adolescents, adults) to isolate their impact on the results.

The overall quality of evidence was evaluated according to Grading of Recommendations Assessment, Development and Evaluation (GRADE) approach using summary of findings table [37].

\section{Results}

\section{Literature flow}

One thousand one hundred eighty-four references were found in the electronic search, and only one more citation was identified from other sources. Duplicate 
references were taken off, and a total of 851 citations were carefully checked. The titles and abstracts were screened for eligibility, and then, all papers which were not fulfilling the inclusion criteria were eliminated. As a result, 24 potentially related trials (12 studies and 12 registry entries for ongoing research work) were examined in depth. Eight of the completed studies and 3 of the ongoing studies were eliminated after full-text reading of the papers (Additional file 3: Table S3: the excluded trials and the reasons for exclusion). Finally, we had 4 studies and 9 ongoing studies to include. The PRISMA flow diagram is shown in Fig. 1.

\section{Characteristics of studies}

The characteristics of the four included trials [17, 38-40] can be found in Table 1 and Additional file 4: Table S4. The nine included protocols were for RCTs trials; more information about these ongoing research projects are given in Table 2 and Additional file 5: Table S5.

Minimally invasive surgical procedures without flap raising or suturing were undertaken in all included studies [17, 38-40]. Two studies evaluated piezocision [38, 40], one tested micro-osteoperforation [17] and one trial investigated the effect of interseptal bone reduction [39]. Sixty-one adult participants 44 female and 17 male were included in the four trials. Extraction treatment (upper canine retraction) was performed in three papers [14, $39,40]$, and only one study was a non-extraction study with mandibular anterior crowding [38]. From the nine protocols for ongoing studies, five investigated the effect of micro-osteoperforations, three tested piezocision and one evaluated both piezocision and microosteoperforation; only two were labelled as 'completed studies'.

\section{Risk of bias of included studies}

Figures 2 and 3 show the summary of the overall risk of bias of the included studies. 'Unclear risk of bias' was the common feature between the four studies. Concealment of allocation as well as participants' blinding were the most problematic fields (unclear in $50 \%, 75 \%$ of studies, respectively). Further details of the assessment of risk of bias can be found in Additional file 6: Table S6.

\section{Effects of interventions}

Primary outcome (rate of tooth movement) Three from the four included trials assessed the effect of minimally invasive corticotomy on the rate of canine retraction after premolar extraction and were considered appropriate for quantitative synthesis $[17,39,40]$; the fourth trial [38] evaluated the effect of piezocision on the rate of alignment in a non-extraction treatment. Therefore, the results of this study could not be pooled to a meta-analysis with the other trials due to the variation in outcomes related to the scenario of orthodontic treatment (extraction, non-extraction).

\section{Canine retraction amount at 1 month}

Three trials compared the cumulative tooth movement of upper canines after the first premolar extraction between conventional and minimally invasive surgical methods after 1 month [17, 39, 40]. The pooled estimate suggested a greater tooth movement by $0.65 \mathrm{~mm}$ with minimally invasive surgical procedures compared to the conventional procedure for the first month of canine retraction, a statistically significant finding (Fig. 4; WMD $=0.65 ; 95 \%$ CI $(0.54,0.76) ; p<0.001)$. Heterogeneity was low $\left(\chi^{2}=0.27, p=0.87, I^{2}=0 \%\right)$. The overall quality of evidence for canine retraction rate at 1 month is very low according to GRADE (Table 3).

\section{Canine retraction amount at 2 months}

Two trials only compared the cumulative tooth movement of upper canines after the first premolar extraction between conventional and minimally invasive surgical methods after an observation period of 2 months [39, 40]. The pooled estimate suggested a greater tooth movement of about $1.41 \mathrm{~mm}$ with minimally invasive surgical procedures compared to the conventional procedure for 2 months of canine retraction, a statistically significant finding (Fig. 5; WMD = $1.41 ; 95 \%$ CI $(0.81,2.01) ; p<0.001)$. Heterogeneity was low $\left(x^{2}=1.16, p=0.28, I^{2}=13 \%\right)$. The overall quality of evidence supporting this outcome is low according to GRADE (Table 3).

\section{Canine retraction amount at 3 months}

Only one trial assessed the cumulative tooth movement of upper canines after the first premolar extraction between conventional and minimally invasive surgical methods after an observation period of 3 months [39]. This study reported a greater tooth movement of about $2 \mathrm{~mm}$ with the minimally invasive surgical procedures compared to the conventional procedure, a statistically significant finding $(\mathrm{MD}=2 ; 95 \% \mathrm{CI}(1.20,2.80))$. The overall quality of evidence supporting this outcome is very low according to GRADE (Table 3).

The trial of Mehr evaluated the influence effect of piezocision on the treatment time required for the relief of lower anterior crowding [38]. This study reported no significant difference in treatment time between conventional and experimental group (118.40 vs. 98.50 days, respectively, $p=0.43 ; \mathrm{MD}=-19.90,95 \% \mathrm{CI}(-59.53$, 19.73)(, whereas the rate of alignment was slightly higher in the experimental compared to control group only during the first month $(p=0.035 ; \mathrm{MD}=-0.04$ : $95 \%$ CI $(-0.07,-0.01))$. 


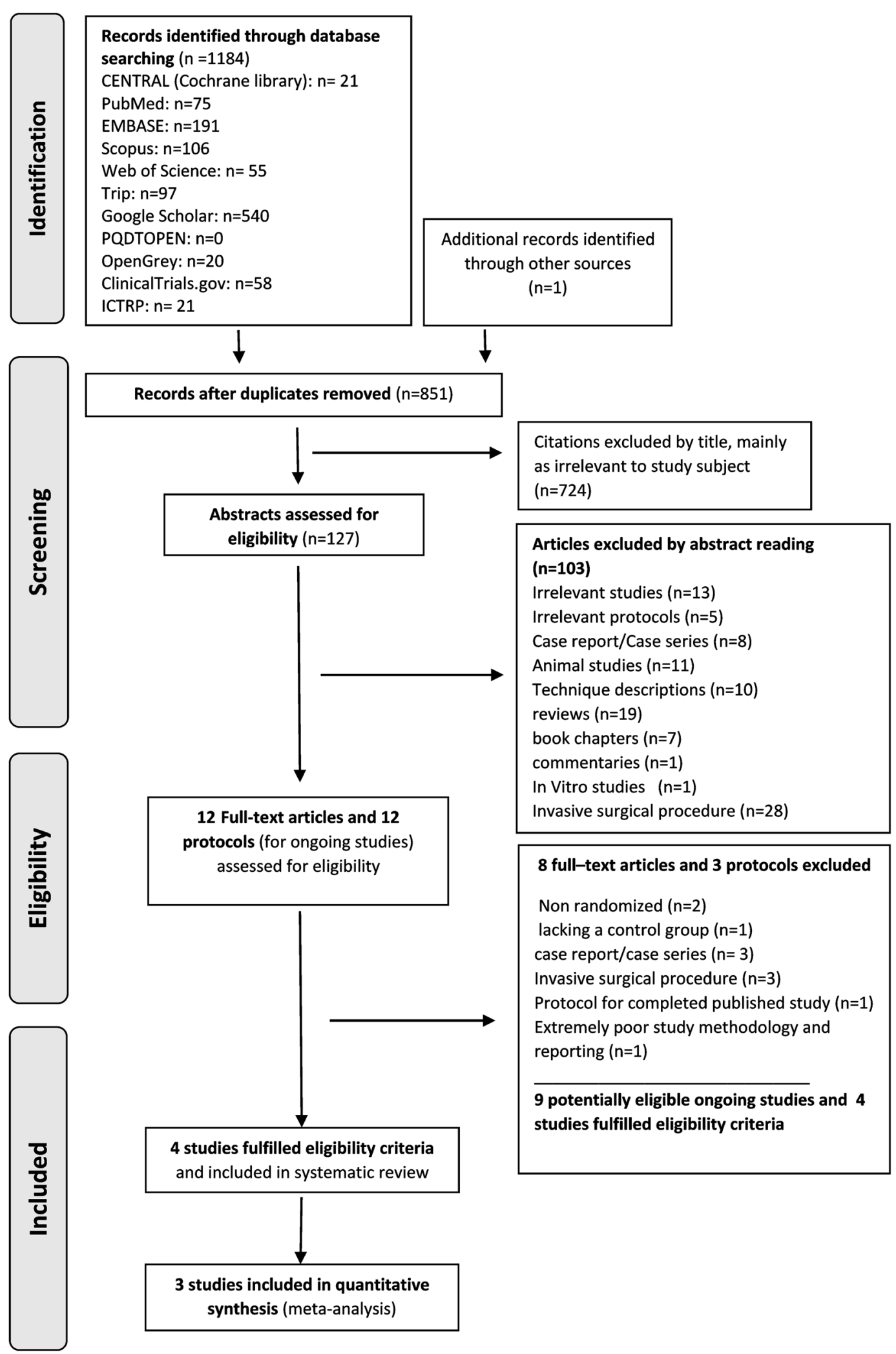

Fig. 1 PRISMA 2009 flow diagram of the included studies 
Table 1 Characteristics of included studies in the systematic review

\begin{tabular}{|c|c|c|c|c|c|c|}
\hline \multirow[t]{2}{*}{ Study/setting } & \multicolumn{2}{|c|}{ Methods } & \multirow{2}{*}{$\begin{array}{l}\text { Participants } \\
\text { Patients (M/F) } \\
\text { Mean age (years) } \\
\text { Malocclusion }\end{array}$} & \multicolumn{2}{|l|}{ Interventions } & \multirow{2}{*}{$\begin{array}{l}\text { Outcomes } \\
\text { Primary and } \\
\text { secondary outcomes }\end{array}$} \\
\hline & $\begin{array}{l}\text { Study } \\
\text { design }\end{array}$ & $\begin{array}{l}\text { Treatment } \\
\text { comparison }\end{array}$ & & $\begin{array}{l}\text { Type and site of } \\
\text { intervention/technical aspects } \\
\text { of interventions }\end{array}$ & $\begin{array}{l}\text { Follow-up } \\
\text { time }\end{array}$ & \\
\hline $\begin{array}{l}\text { Alikhani } 2013 \\
\text { [17] } \\
\text { New York } \\
\text { USA }\end{array}$ & $\begin{array}{l}\text { RCT } \\
\text { COMP }\end{array}$ & $\begin{array}{l}\text { MOP + OT } \\
\text { vs. OT }\end{array}$ & $\begin{array}{l}\text { Patients (M/F): } 20 \text { (8/12) } \\
\text { Control: 10, Exp: } 10 \\
\text { Mean age: } \\
\text { Control: } 24,7 \text { Exp:26, } 8 \\
\text { Malocclusion: class II div.1 }\end{array}$ & $\begin{array}{l}\text { - MOPs (upper canines) } \\
\text { - No flap elevation, three small MOPs were } \\
\text { done in the extraction area at equivalent } \\
\text { spaces between the canine and the second } \\
\text { premolar after } 6 \text { months from maxillary } \\
\text { first premolar extraction. Each perforation } \\
\text { was } 1.5 \mathrm{~mm} \text { wide and } 2 \text { to } 3 \mathrm{~mm} \text { deep. } \\
\text { Surgical instrument: a disposable handled } \\
\text { device orthodontic activation: } \\
\text { immediately following the intervention }\end{array}$ & 4 weeks & $\begin{array}{l}\text { Primary outcome: } \\
\text { RTM (mm/month) } \\
\text { Secondary outcomes: } \\
\text {-Pain and discomfort } \\
\text {-Inflammatory markers } \\
\text { (cytokines levels) }\end{array}$ \\
\hline $\begin{array}{l}\text { Mehr } 2013[38] \\
\text { Connecticut } \\
\text { USA }\end{array}$ & $\begin{array}{l}\mathrm{RCT} \\
(\mathrm{PG})\end{array}$ & $\begin{array}{l}\text { Piezocision } \\
\text { + OT vs. OT }\end{array}$ & $\begin{array}{l}\text { Patients (M/F): } 13 \text { (5/8) } \\
\text { Control: } 6 \text { Exp: } 7 \\
\text { Mean age (years): } \\
\text { Control: 26, } 35 \text { Exp: 29, } 12 \\
\text { Malocclusion: mandibular } \\
\text { anterior crowding } \\
\text { (irregularity index } \\
\text { greater than 5) }\end{array}$ & $\begin{array}{l}\text { - Piezocision (mandibular incisors) } \\
\text { - No flap elevation, three vertical incisions, } \\
\text { (4 mm length and } 1 \mathrm{~mm} \text { depth of cortical } \\
\text { bone), interproximally between mandibular } \\
\text { canines and lateral incisors, and central } \\
\text { incisors. Surgical instrument: piezosurgery } \\
\text { knife (BS1) orthodontic activation: } \\
\text { immediately following the intervention }\end{array}$ & $\begin{array}{l}\text { Until } \\
\text { complete } \\
\text { decrowding }\end{array}$ & $\begin{array}{l}\text { Primary outcome: } \\
\text {-RTM (mm/month) } \\
\text {-TTM (days) } \\
\text { Secondary outcomes: } \\
\text { pain }\end{array}$ \\
\hline $\begin{array}{l}\text { Leethanakul } \\
2014 \text { [39] } \\
\text { Thailand }\end{array}$ & $\begin{array}{l}\mathrm{RCT} \\
\text { (SP) }\end{array}$ & $\begin{array}{l}\text { Interseptal } \\
\text { bone } \\
\text { reduction } \\
\text { + OT vs. } \\
\text { OT }\end{array}$ & $\begin{array}{l}\text { Patients (M/F): } \\
18 \text { (0/18( } \\
\text { Control: } 18, \text { Exp: } 18 \\
\text { Mean age (years): } 21.9 \pm 4.7 \\
\text { Malocclusion: patients who } \\
\text { need to extract maxillary } \\
\text { 1st premolars and maxillary } \\
\text { canine retraction }\end{array}$ & $\begin{array}{l}\text { - Interseptal bone reduction (upper canines) } \\
\text { - No flap elevation, reduction ( } 1.0 \text { to } \\
1.5 \mathrm{~mm} \text { ) of the interseptal bone distal to the } \\
\text { canine inside the extraction socket of the } \\
\text { first premolar. Surgical instrument: bur } \\
\text { orthodontic activation: immediately } \\
\text { following the intervention }\end{array}$ & $\begin{array}{l}\text { Up to } \\
3 \text { months } \\
\text { after } \\
\text { intervention }\end{array}$ & $\begin{array}{l}\text { Primary outcome: } \\
\text {-RTM (mm/month) } \\
\text {-CTM (mm) } \\
\text { Secondary outcomes: } \\
\text { Canine tipping } \\
\text { Canine rotation }\end{array}$ \\
\hline $\begin{array}{l}\text { Aksakalli } 2015 \\
{[40]} \\
\text { Istanbul Turkey }\end{array}$ & $\begin{array}{l}\mathrm{RCT} \\
\text { (SP) }\end{array}$ & $\begin{array}{l}\text { Piezocision } \\
\text { + OT vs. OT }\end{array}$ & $\begin{array}{l}\text { Patients (M/F): } 10(4 / 6) \\
\text { Control: 10, Exp: } 10 \\
\text { Mean age (years): } 16.3 \pm 2.4 \\
\text { (adult only) } \\
\text { Malocclusion: half or more } \\
\text { unit class II malocclusion }\end{array}$ & $\begin{array}{l}\text { - Piezocision (upper canines) } \\
\text { - No flap elevation, two vertical } \\
\text { interproximal incisions were performed } \\
\text { mesial and distal of the maxillary canines, } \\
5 \mathrm{~mm} \text { apical to interdental papilla, incision } \\
\text { lengths were approximately } 10 \mathrm{~mm} \text { apically, } \\
3 \mathrm{~mm} \text { deep in cortical alveolar. Surgical } \\
\text { instrument: piezosurgery knife (BS1) } \\
\text { orthodontic activation: immediately } \\
\text { following the intervention. }\end{array}$ & $\begin{array}{l}\text { Up to ideal } \\
\text { class I canine } \\
\text { relation-ship }\end{array}$ & $\begin{array}{l}\text { Primary outcome: } \\
\text {-CTM (mm) } \\
\text {-TTM (months) } \\
\text { Secondary outcomes: } \\
\text { - Molar anchorage loss } \\
\text { - Transversal changes } \\
\text { - Mobility scores } \\
\text { - Gingival indices }\end{array}$ \\
\hline
\end{tabular}

$R C T$ randomized clinical trial, $O T$ orthodontic therapy, $P G$ parallel-group design, $S P$ split-mouth design, COMP compound design (parallel-group design and one arm is a split-mouth design), MOPs micro-osteoperforations, Exp experimental, NR not reported, $M$ male, $F$ female, U3 upper canines, SS stainless steel, RTM rate of tooth movement, TTM time of tooth movement, CTM cumulative tooth movement

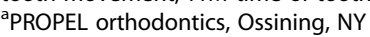

Secondary outcomes Two trials evaluated the levels of pain associated with minimally invasive surgical procedures $[17,38]$; we could not pool the results to quantitative synthesis due to the difference between the two studies in the provided treatment (extraction vs. nonextraction, retraction vs. relief of crowding). Alikhani assessed pain and discomfort levels during canine retraction using numeric rating scale, and there was no significant difference between the control and experimental sides $(p>0.5)$ at $1,7,14$ and 28 days after retraction [17]. A visual analogue scale was used by Mehr for the assessment of pain when acceleration of tooth decrowding was under inspection, and there was no significant difference between the control and experimental groups immediately, 1 and $12 \mathrm{~h}$ and 7 days after the piezo-surgical intervention $(p>0.05)$ [38].
Gingival and periodontal problems, including gingival inflammation and mobility for the retracted canines, were evaluated in a one split-mouth design study [40]. There was no significant difference in the mobility scores between the control and the experimental sides pre- and post-distalization $(p>0.05)$. Similarly, there was no significant difference in gingival indices between both sides pre and post-distalization $(p>0.05)$.

Undesirable posterior and anterior tooth movements were inspected in two studies. Aksakalli investigated molar anchorage loss and transversal changes of the upper canines and first upper molars. There was a significant decrease in loss of anchorage in the piezocision side compared to the control side $(p<0.05)$. For transversal measurements related to the distance from the mid-palatal suture to the upper canine/first molar, there 
Table 2 Protocols of the ongoing studies registered at the clinical.trials.gov and the ANZCTR

\begin{tabular}{|c|c|c|c|c|c|}
\hline Study ID & Trial name or title & Study design & $\begin{array}{l}\text { Intervention }+ \\
\text { treatment } \\
\text { comparison }\end{array}$ & $\begin{array}{l}\text { Sample size/age/ } \\
\text { gender }\end{array}$ & Outcomes \\
\hline NCT02606331 & $\begin{array}{l}\text { Efficacy of minimally invasive } \\
\text { surgical technique in } \\
\text { accelerating orthodontic } \\
\text { treatment }\end{array}$ & $\begin{array}{l}\text {-RCT/PG } \\
\text {-Single blind } \\
\text { (outcomes assessor) }\end{array}$ & $\begin{array}{l}\text {-Piezocision + } \\
\text { OT vs. OT } \\
\text { - MOPs } \\
\text { accomplished } \\
\text { by ER: YAG } \\
\text { laser + OT vs. } \\
\text { OT }\end{array}$ & $\begin{array}{l}\text { 36/15-27/both } \\
\text { (male, females) }\end{array}$ & $\begin{array}{l}\text { Primary outcomes: rate of } \\
\text { canine retraction } \\
\text { Secondary outcomes: rate of } \\
\text { molar anchorage loss/canine } \\
\text { rotation/levels of pain and } \\
\text { discomfort }\end{array}$ \\
\hline NCT02359760 & $\begin{array}{l}\text { Assessment of piezoelectric } \\
\text { periodontal surgery effects } \\
\text { on orthodontic treatment: } \\
\text { a prospective pilot study }\end{array}$ & $\begin{array}{l}\text { - RCT/PG } \\
\text {-Single blind } \\
\text { (outcomes assessor) }\end{array}$ & $\begin{array}{l}\text { Piezocision + } \\
\text { OT vs. OT }\end{array}$ & $\begin{array}{l}\text { EXP:20, } \\
\text { CON:40/18-40/both } \\
\text { (male, females) }\end{array}$ & $\begin{array}{l}\text { Primary outcomes: duration of } \\
\text { orthodontic treatment } \\
\text { Secondary outcomes: compare } \\
\text { the duration of treatment with } \\
\text { the control group/overall quality } \\
\text { of treatment (ABO) } \\
\text { standards/pain/inflammatory } \\
\text { markers/density and bone } \\
\text { volume/root resorption }\end{array}$ \\
\hline NCT02590835 & $\begin{array}{l}\text { Efficiency of piezocision- } \\
\text { assisted orthodontic } \\
\text { treatment in adult patients }\end{array}$ & $\begin{array}{l}\text { - RCT/PG } \\
\text {-Open label }\end{array}$ & $\begin{array}{l}\text { Piezocision + } \\
\text { OT vs. OT }\end{array}$ & $\begin{array}{l}24 / 21 \text { years and } \\
\text { older/both (male, } \\
\text { females) }\end{array}$ & $\begin{array}{l}\text { Primary outcomes: overall } \\
\text { treatment time measurement. } \\
\text { Secondary outcomes: root } \\
\text { resorption/periodontal } \\
\text { parameters/patient-centred } \\
\text { outcomes }\end{array}$ \\
\hline NCT01720797 & $\begin{array}{l}\text { Alveolar micro-perforation } \\
\text { for inflammation-enhanced } \\
\text { tooth movement during } \\
\text { orthodontic treatment } \\
\text { (propel) }\end{array}$ & $\begin{array}{l}\text { - RCT/PG } \\
\text { - Open label }\end{array}$ & $\begin{array}{l}\text { MOPs + OT vs. } \\
\text { OT }\end{array}$ & $\begin{array}{l}\text { 15/18-55/both } \\
\text { (male, females) }\end{array}$ & $\begin{array}{l}\text { Primary outcomes: } \\
\text { tooth movement } \\
\text { Secondary outcomes: NR }\end{array}$ \\
\hline NCT02549950 & $\begin{array}{l}\text { Efficiency of piezo-corticision } \\
\text { in accelerating orthodontic } \\
\text { tooth movement }\end{array}$ & $\begin{array}{l}\text { - RCT/PG } \\
\text { - Open label }\end{array}$ & $\begin{array}{l}\text { Peizo- } \\
\text { corticision + } \\
\text { OT vs. OT }\end{array}$ & $\begin{array}{l}\text { NR/15-35/both } \\
\text { (male, females) }\end{array}$ & $\begin{array}{l}\text { Primary outcomes: rate of } \\
\text { orthodontic canine movement. } \\
\text { Secondary outcomes: rate of } \\
\text { orthodontic incisor retraction/ } \\
\text { quality of treatment } \\
\text { outcome (ABO) standards }\end{array}$ \\
\hline NCT02473471 & $\begin{array}{l}\text { Micro-osteoperforation and } \\
\text { tooth movement }\end{array}$ & $\begin{array}{l}\text { - RCT/PG } \\
\text {-Double blind } \\
\text { (investigator } \\
\text { outcomes assessor) }\end{array}$ & $\begin{array}{l}\text { MOPs + OT vs. } \\
\text { OT }\end{array}$ & $\begin{array}{l}\text { 40/13-45/both } \\
\text { (males, females) }\end{array}$ & $\begin{array}{l}\text { Primary outcomes: rate of tooth } \\
\text { movement } \\
\text { Secondary outcomes: pain/root } \\
\text { resorption/patient satisfaction }\end{array}$ \\
\hline NCT02571348 & $\begin{array}{l}\text { Optimum micro- } \\
\text { osteoperforations accelerated } \\
\text { tooth movement interval }\end{array}$ & $\begin{array}{l}\text {-RCT/PG } \\
\text {-Single blind } \\
\text { (outcomes assessor) }\end{array}$ & $\begin{array}{l}\text { MOPs + OT vs. } \\
\text { OT }\end{array}$ & $\begin{array}{l}\text { 36/18-45/both } \\
\text { (males, females) }\end{array}$ & $\begin{array}{l}\text { Primary outcomes: rate of } \\
\text { orthodontic tooth } \\
\text { movement } \\
\text { Secondary outcomes: rate of } \\
\text { orthodontic } \\
\text { tooth movement between } \\
\text { maxilla and mandible and when } \\
\text { micro-osteoperforations } \\
\text { performed at 4-, 8- and 12-week } \\
\text { intervals/pain. }\end{array}$ \\
\hline NCT02416297 & $\begin{array}{l}\text { Three-dimensional evaluation } \\
\text { of accelerated tooth } \\
\text { movement }\end{array}$ & $\begin{array}{l}\text { - RCT/PG } \\
\text { - Open label }\end{array}$ & $\begin{array}{l}\text { MOPs + OT vs. } \\
\text { OT }\end{array}$ & $\begin{array}{l}\text { 50/16-60/both } \\
\text { (males, females) }\end{array}$ & $\begin{array}{l}\text { Primary outcomes: velocity rate } \\
\text { of anterior retraction/bone } \\
\text { demineralization } \\
\text { Secondary outcomes: NR }\end{array}$ \\
\hline $\begin{array}{l}\text { ACTRN12615000593538 } \\
\text { Register: ANZCTR }\end{array}$ & $\begin{array}{l}\text { The effects of micro- } \\
\text { osteoperforations } \\
\text { on orthodontic root } \\
\text { resorption and tooth } \\
\text { movement—a pilot study }\end{array}$ & $\begin{array}{l}\text {-RCT/SP } \\
\text {-Double blind } \\
\text { (investigator, } \\
\text { outcomes assessor) }\end{array}$ & $\begin{array}{l}\text { MOPs + OT vs. } \\
\text { OT }\end{array}$ & $\begin{array}{l}\text { 15/12-18/both } \\
\text { (males, Females) }\end{array}$ & $\begin{array}{l}\text { Primary outcomes: root } \\
\text { resorption } \\
\text { Secondary outcomes: } \\
\text { orthodontic tooth movement/ } \\
\text { level of discomfort }\end{array}$ \\
\hline
\end{tabular}

$R C T$ randomized clinical trial, $P G$ parallel-group design, $S P$ split-mouth design, MOPs micro-osteoperforations, $O T$ orthodontic therapy, NR not reported, EXP experimental group, $C O N$ control group, $A B O$ American Board of Orthodontics' grading system 


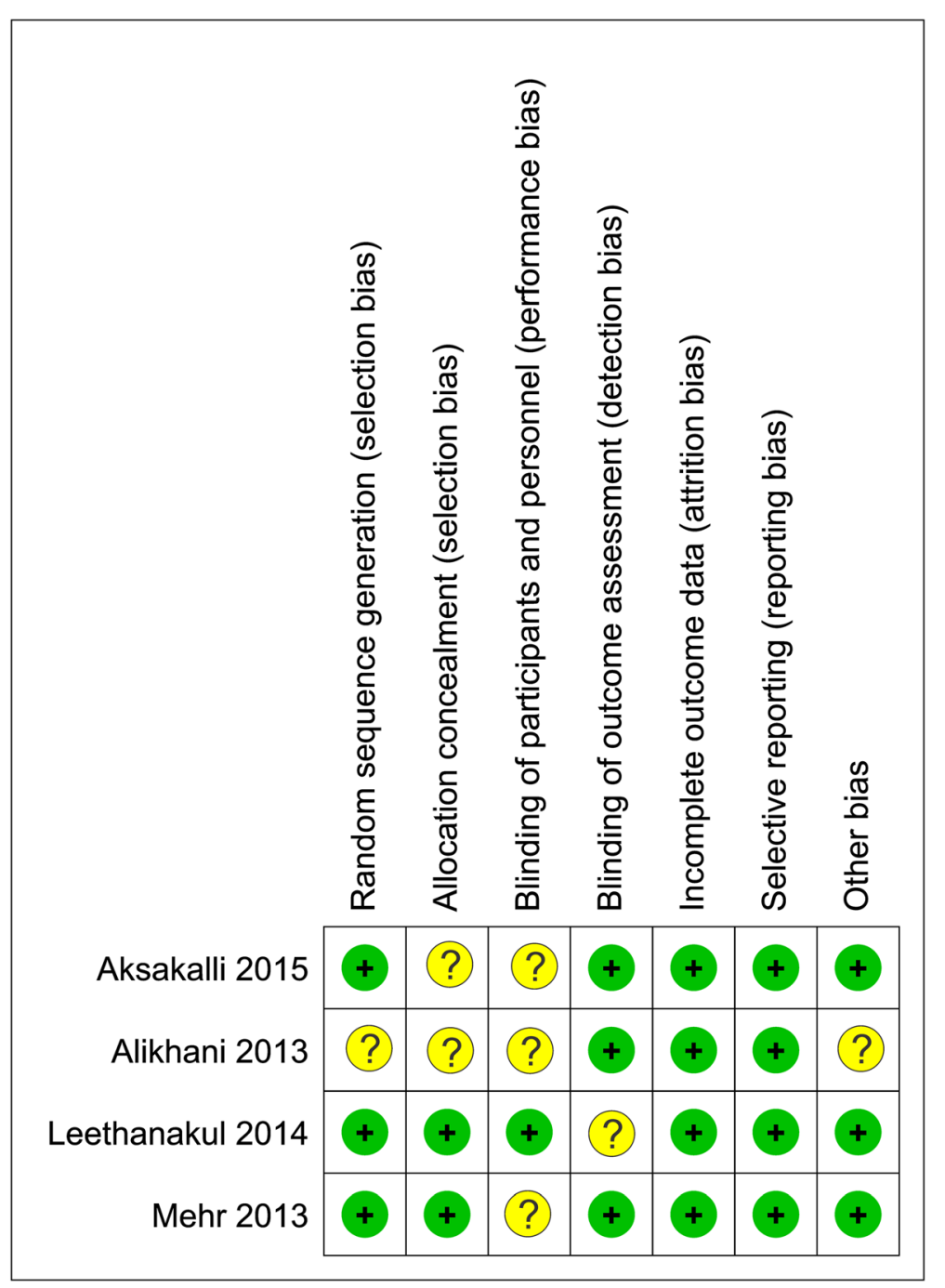

Fig. 2 Risk of bias summary of RCTs. Low risk of bias (the plus sign); unclear risk of bias (the question mark sign)

was no significant difference between the two sides $(p>$ $0.05)$ [40]. On the other hand, for the untoward side effects following retraction of anterior teeth, Leethanakul studied both canine tipping and rotation and there were no significant differences between the control and the experimental sides $(p>0.05)$ [39].

\section{Discussion}

Minimally invasive surgically accelerated orthodontics (MISAO) has captured the attention of the orthodontic community in recent years. The increased number of registered clinical trials in this domain has reflected the great interest in this topic. According to this systematic review, it appears that there is a low evidence showing a significant advantage of the minimally invasive surgical procedures relative to the possible associated adverse effects. We included only the randomized controlled trials to minimize bias and possible confounders. MISAO has been evaluated in four trials which were judged to be at unclear risk of bias; this could have potentially confused the results.

Three trials investigated the efficacy of minimally invasive surgical procedures in accelerating canine retraction after premolars extraction $[17,39,40]$, and they reported a greater tooth movement with the minimally invasive surgical procedures compared to the conventional method by 0.65 and $1.41 \mathrm{~mm}$ for the first and second months, respectively. However, the effectiveness of these procedures is doubtful over time since the impact on the overall treatment time was not investigated. Whereas only one included study evaluated the effectiveness of minimally invasive surgical procedures in accelerating alignment (non-extraction treatment) and reported no significant difference in the overall treatment time between the conventional and the experimental groups [38]. When comparing the findings of this non-extraction- 


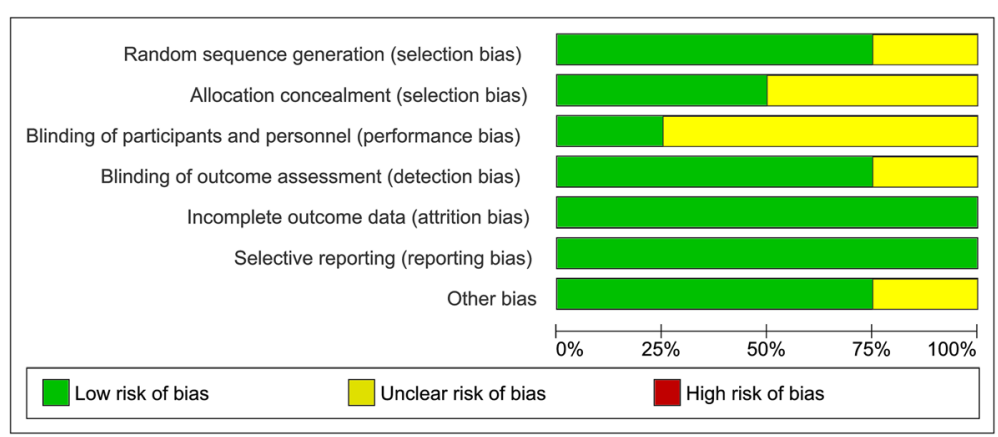

Fig. 3 Overall risk of bias score for each field

based trial [38] with the three previous extraction-based studies $[17,39,40]$, it seems that the treatment type could have an influence on the accelerating rate. An explanation for this may be due to the difference in the type of movement (rotation, tipping, bodily movement) or due to the application site or bone density (mandibular vs. maxillary arch).

The previous included studies assessed different minimally invasive surgical procedures piezocision $[38,40]$, MOPs [17] and interseptal bone reduction [39] with variations on the size and design of the flapless corticotomy cuts; in addition, there was a variation on the used tools to perform these procedures, such as piezosurgical tools [38, 40], disposable perforating devices [17] and lasers [30]. Therefore, it is important that future studies test the effect of these differences in (surgical protocol, size and design of cuts, tools) on the amount of accelerating, treatment costs and the adverse side effects of each individual intervention.

Sixty-one participants were included in the four studies, and this number is relatively small. More prospective RCTs with increased sample size are required. The four trials included only adult patients; therefore, the effectiveness of these procedures in adolescent patients was not confirmed.

Gender can be considered a confounding factor when analysing bone remodelling and the rate of tooth movement. However, the effect of gender was not isolated in this review because of the small number of studies included as well as the small sample sizes employed.

Moreover, the reduction of the tooth movement rate is apparent after the first month of application [17] or after the second month [39]. One possible explanation is the transient nature of the RAP which is manifested by a decline in the tooth movement rate over time [13, 15]. Therefore, the possible advantage of these minimally invasive procedures might be weakened over the time making it of little value at the final assessment of outcome. Therefore, future research should evaluate the effect of repeated interventions on decreasing overall treatment time as well as the possible untoward effects on the periodontal tissues.

No adverse effects of MISAO on periodontal tissues were reported in the included trials [40]. However, the assessment did not take into account important variables such as plaque index, probing depth, attachment loss and gingival recession.

Two included trials investigated the unwanted tooth movements (canine tipping and rotation, molar anchorage loss, transverse changes) associated with MISAO $[39,40]$. No significant unwanted tooth movements were reported; conversely, Aksakalli found less loss of molar anchorage in the piezocision side compared to the control side [40]. This may be explained by the possible localized alveolar response in the injury area which did not extend backwards to the posterior segments.

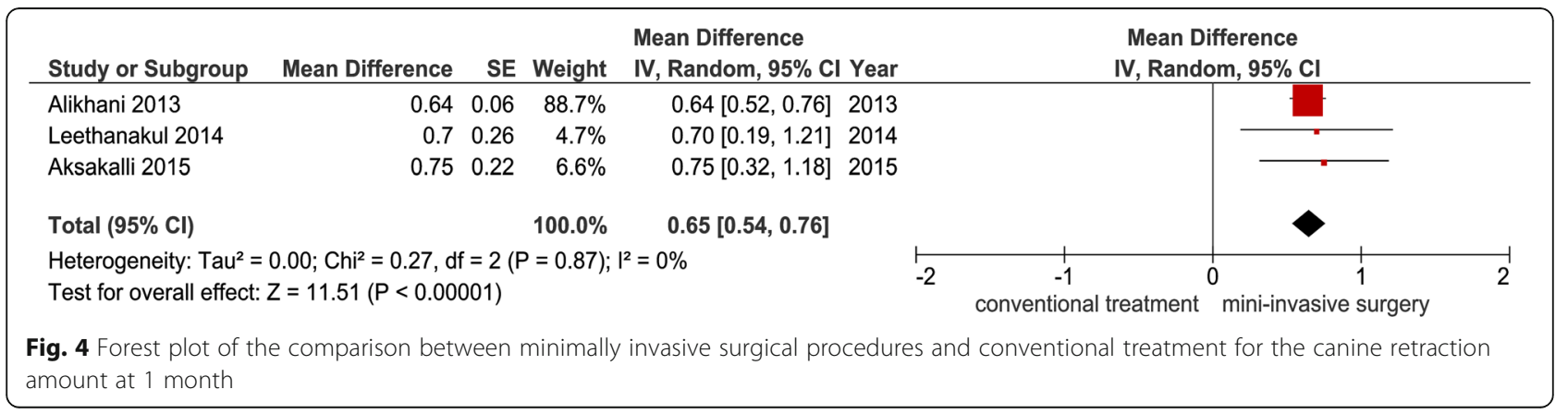


Table 3 Summary of findings table according to the GRADE guidelines for the included trials

Patient or population: patients need orthodontic treatments, settings: upper canines (RCT), intervention: minimally invasive surgical procedures, comparison: conventional treatment

\begin{tabular}{|c|c|c|c|c|}
\hline Outcomes & $\begin{array}{l}\text { Weighted mean difference }(95 \% \mathrm{Cl}) \\
\text { between minimally invasive surgical } \\
\text { assisted vs. conventional retraction }\end{array}$ & $\begin{array}{l}\text { No. of } \\
\text { participants } \\
\text { (studies) }\end{array}$ & $\begin{array}{l}\text { Quality of the } \\
\text { evidence (GRADE) }\end{array}$ & Comments \\
\hline $\begin{array}{l}\text { Orthodontic tooth } \\
\text { movement in } \mathrm{mm} \\
\text { ( } 2 \text { months) }\end{array}$ & $\begin{array}{l}\text { The mean canine retraction in } \\
\text { the intervention groups was } \\
1.41 \text { higher }(0.81 \text { to } 2.01 \text { higher). } \\
\text { Relative effect ( } 95 \% \mathrm{Cl}) \text { : } \\
\text { not estimable }\end{array}$ & $\begin{array}{l}28 \\
(2 \text { studies SP) }\end{array}$ & $\begin{array}{l}\oplus \oplus \Theta^{a} \\
\text { Low }\end{array}$ & $\begin{array}{l}\text { This outcome also measured at } 1 \text { month in } 3 \text { studies } \\
\text { ( } 38 \text { patients): mean canine retraction in the } \\
\text { intervention groups was } 0.65 \text { higher } \\
\text { ( } 0.54 \text { to } 0.76 \text { higher) with a quality of evidence very } \\
\text { low } \oplus \Theta \Theta \Theta^{b} \text {. } \\
\text { Also, this outcome was assessed at } 3 \text { months in one } \\
\text { study ( } 18 \text { patients). This study reported higher tooth } \\
\text { movement by } 2 \mathrm{~mm} \text { with the minimally invasive } \\
\text { surgical procedure, a statistically significant finding } \\
\text { (MD = 2: } 95 \% \mathrm{Cl} 1.20 \text { to } 2.80 \text { ) with a quality of } \\
\text { evidence very low } \oplus \Theta \Theta \Theta^{c} \text {. }\end{array}$ \\
\hline
\end{tabular}

$\begin{array}{llll}\begin{array}{l}\text { Pain and } \\ \text { discomfort }\end{array} & \begin{array}{l}\text { See comments } \\ \text { Relative effect }(95 \% \mathrm{Cl}):\end{array} & 10 & \oplus \Theta \Theta \Theta^{d} \\ \text { not estimable } & (1 \text { study, COMP) } & \text { Very low } \\ & 13(1 \text { study, PG) } & \begin{array}{l}\oplus \oplus \Theta \Theta^{e} \\ \text { Low }\end{array}\end{array}$

The difference between the control and experimental groups was not significant $(p>0.5)$ at $1,7,14$ and 28 days after retraction.

There was no significant difference in the level of pain between the two groups immediately, 1 and $12 \mathrm{~h}$ and 7 days after piezocision $(p>0.05)$.

We could not pool the results of the previous 2 trials which evaluated this outcome to quantitative synthesis due to differences in specific treatments (non-extraction vs. extraction).

Adverse effects (periodontal problems)

Adverse effects anchorage loss

Adverse effects (unwanted tooth movement)

\author{
See comments \\ Relative effect $(95 \% \mathrm{Cl})$ : \\ not estimable
}

There was no significant difference in mobility scores of canines between the control and experimental groups pre- and post-distalization ( $p>0.05$ ). Similarly, there was no significant difference in gingival indices between both groups pre- and post-distalization $(p>0.05)$.

$\begin{array}{lcl}\begin{array}{l}\text { See comments } \\ \text { Relative effect }(95 \% \text { Cl): } \\ \text { not estimable }\end{array} & 10 \text { (1 study, SP) } & \begin{array}{l}\oplus \oplus \Theta \Theta^{f} \\ \text { Low }\end{array} \\ \begin{array}{l}\text { See comments } \\ \text { Relative effect }(95 \% \text { Cl): } \\ \text { not estimable }\end{array} & 18(1 \text { study, SP) } & \begin{array}{l}\oplus \oplus \Theta \Theta^{9} \\ \text { Low }\end{array} \\ & 10(1 \text { study, SP) } & \begin{array}{l}\oplus \oplus \Theta \Theta^{f} \\ \text { Low }\end{array}\end{array}$

There was significant difference in loss of anchorage between control and experimental groups $(p<0.05)$, the anchorage loss was lesser in the piezocision group.

There was no significant difference between control and experimental sides for canine tipping and rotation $(p>0.05)$.

There was no significant difference between control and experimental sides for transversal changes $(p>0.05)$.

\footnotetext{
High quality: further research is very unlikely to change our confidence in the estimate of effect. Moderate quality: further research is likely to have an important impact on our confidence in the estimate of effect and may change the estimate. Low quality: further research is very likely to have an important impact on our confidence in the estimate of effect and is likely to change the estimate. Very low quality: we are very uncertain about the estimate

$\mathrm{Cl}$ confidence interval, $P G$ parallel-group design, SP split-mouth design, COMP compound design, GRADE working group grades of evidence

${ }^{a}$ Decline one level for risk of bias (blinding of outcome assessment unclear [39], blinding of participants and personnel and allocation concealment unclear in [40]) and one level for indirectness*

${ }^{b}$ Decline two levels for risk of bias (blinding of participants and personnel and allocation concealment unclear [17, 40], blinding of outcome assessment unclear [39]), random sequence generation and bias due to conflict of interest unclear [17]) and one level for indirectness*

'Decline one level for risk of bias (blinding of outcome assessment unclear [39]), and one level for indirectness*, and one level for imprecision**

${ }^{\mathrm{d}}$ Decline two levels for risk of bias (unclear risk of bias of randomization, allocation concealment, blinding of participants and personnel and conflict of interest [17]) and one level for imprecision**

eDecline one level for risk of bias (unclear risk of bias of blinding of participants and personnel [17]) and one level for imprecision**

${ }^{f}$ Decline one level for risk of bias (unclear risk of bias of blinding of participants and personnel and allocation concealment [40]) and one level for imprecision** ${ }^{9}$ Decline one level for risk of bias (unclear risk of bias of blinding of outcome assessment [39]) and one level for imprecision**

*Outcome is not directly related; the included trials involved only adult patients, so the efficacy of minimally invasive surgical procedures could not be confirmed on adolescent patients. Also, patient-centred outcomes were very limited
}

**Limited number of trials, of limited sample size

No significant levels of pain and discomfort associated with MISAO were reported [17, 38]. This can be attributed to the conservative nature of these surgical interventions since no flap reflection or suturing was required.
Although no important adverse effects associated with MISAO were reported in the evaluated four trials, there is no scientific evidence to support the absence or presence of post-operative infection, bleeding, swelling, root resorption, loss of tooth vitality and possible morbidity 


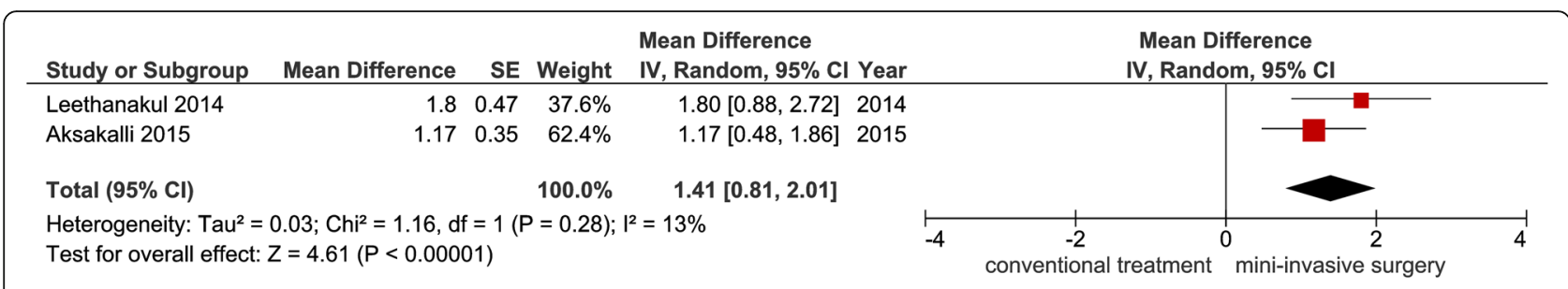

Fig. 5 Forest plot of the comparison between minimally invasive surgical procedures and conventional treatment for the canine retraction amount at 2 months

following such procedures. It is therefore suggested that future work should consider these effects and patient-reported outcomes. Although a meticulous approach was employed in the current review to retrieve the relevant papers that would answer the focused review question, there are still some limitations due to the variability between the included trials in fixed appliance characteristics, biomechanics of tooth movement, and the methods of outcome measurements.

\section{Conclusions}

There is limited and low-quality evidence concerning the efficacy of MISAO in acceleration orthodontic tooth movement. Therefore, the results of this systematic review should be taken carefully, and there is a need for more research with additional attention paid to sample size, overall treatment follow-up, the applied surgical protocol (extent, size and design of surgical cuts), the type of the minimally invasive techniques (piezocision, micro-osteoperforations, interseptal bone reduction, corticision, lasercision), the type of orthodontic treatments (extraction vs. non-extraction), the number of surgical interventions (single vs. repeated interventions), adverse effects and cost-benefit ratio. MISAO cannot currently be recommended in everyday clinical practice, although the acceleration of canine retraction appeared to be significant at least in the first 2 months according to this review.

\section{Additional files}

Additional file 1: Table S1. Electronic Search Strategy. (DOCX 19 kb)

Additional file 2: Table S2. Search strategy for trials' registries. (DOCX $13 \mathrm{~kb}$ )

Additional file 3: Table S3. Excluded studies and the reasons beyond exclusion. (DOCX $16 \mathrm{~kb}$ )

Additional file 4: Table S4. (Supplemental to Table 1): Additional Characteristics of the included studies. (DOCX $16 \mathrm{~kb}$ )

Additional file 5: Table S5. (Supplementary to Table 2): Additional Characteristics of the protocols (ongoing studies). (DOCX $15 \mathrm{~kb}$ )

Additional file 6: Table S6. Risk of bias. (DOCX 16 kb)

\section{Abbreviations}

CCTs: Controlled clinical trials; CENTRAL: The Cochrane Central Register of Controlled Trials; Cl: Confidence intervals; CTM: Cumulative distance of tooth movement; GRADE: Grading of Recommendations Assessment Development and Evaluation; MD: Mean differences; MISAO: Minimally invasive surgically accelerated orthodontics; MOPs: Micro-osteoperforations; PRISMA: Preferred Reporting Items for Systematic Reviews and Meta-Analyses; r: Correlation coefficient; RAP: Regional accelerated phenomena; RCTs: Randomized controlled trials; RTM: Rate of tooth movement; SD: Standard deviation; SE: Standard error; WMD: Weighted mean difference

\section{Acknowledgements}

The review authors would like to thank D Ghaddy Al-Saty (West Virginia University, USA) for her valuable assistance in many aspects of this review.

\section{Funding}

This review was not funded.

\section{Authors' contributions}

AMHA and MYH performed the electronic search, AMHA and MYH collected and analysed the data, AMHA and MYH assessed the risk of bias of included studies, MYH and MAA performed the statistical analysis and AMHA and $\mathrm{MYH}$ drafted the Manuscript. All of the authors were involved in the interpretation of the data. All of the authors provided the feedback on the revisions of the manuscript. All authors read and approved the final manuscript.

\section{Competing interests}

The authors declare that they have no competing interests.

\section{Author details}

${ }^{1}$ Orthodontics Department, University of Damascus Dental School, Damascus, Syria. ${ }^{2}$ Oral Medicine Department, University of Damascus Dental School, Damascus, Syria. ${ }^{3}$ Oral and Maxillofacial Surgery Department, University of Damascus Dental School, Damascus, Syria.

Received: 30 July 2016 Accepted: 19 September 2016

Published online: 24 October 2016

References

1. Tsichlaki A, Chin SY, Pandis N, Fleming PS. How long does treatment with fixed orthodontic appliances last? A systematic review. Am J Orthod Dentofacial Orthop. 2016;149:308-18.

2. Fisher MA, Wenger RM, Hans MG. Pretreatment characteristics associated with orthodontic treatment duration. Am J Orthod Dentofacial Orthop. 2010;137:178-86.

3. Mavreas D, Athanasiou AE. Factors affecting the duration of orthodontic treatment: a systematic review. Eur J Orthod. 2008;30:386-95.

4. Talic NF. Adverse effects of orthodontic treatment: a clinical perspective. Saudi Dent J. 2011;23:55-9.

5. Segal GR, Schiffman PH, Tuncay OC. Meta analysis of the treatment-related factors of external apical root resorption. Orthod Craniofac Res. 2004;7:71-8.

6. Rosvall MD, Fields HW, Ziuchkovski J, Rosenstiel SF, Johnston WM. Attractiveness, acceptability, and value of orthodontic appliances. Am J Orthod Dentofacial Orthop. 2009;135:276-7.

7. Uribe F, Padala S, Allareddy V, Nanda R. Patients', parents', and orthodontists' perceptions of the need for and costs of additional procedures to reduce treatment time. Am J Orthod Dentofacial Orthop. 2014;145:S65-73. 
8. Fathimani M, Melenka GW, Romanyk DL, Toogood RW, Heo G, Carey JP, Major PW. Development of a standardized testing system for orthodontic sliding mechanics. Prog Orthod. 2015;16:14.

9. Kau CH, Kantarci A, Shaughnessy T, Vachiramon A, Santiwong P, de la Fuente A, Skrenes D, Ma D, Brawn P. Photobiomodulation accelerates orthodontic alignment in the early phase of treatment. Prog Orthod. 2013;14:30.

10. McGorray SP, Dolce C, Kramer S, Stewart D, Wheeler TT. A randomized, placebo-controlled clinical trial on the effects of recombinant human relaxin on tooth movement and short-term stability. Am J Orthod Dentofacial Orthop. 2012;141:196-203.

11. Cruz DR, Kohara EK, Ribeiro MS, Wetter NU. Effects of low-intensity laser therapy on the orthodontic movement velocity of human teeth: a preliminary study. Lasers Surg Med. 2004;35:117-20.

12. Nimeri G, Kau CH, Abou-Kheir NS, Corona R. Acceleration of tooth movement during orthodontic treatment-a frontier in orthodontics. Prog Orthod. 2013;14:42.

13. Wilcko WM, Wilcko T, Bouquot JE, Ferguson DJ. Rapid orthodontics with alveolar reshaping: two case reports of decrowding. Int J Periodontics Restorative Dent. 2001;21:9-19.

14. Wilcko MT, Wilcko WM, Bissada NF. An evidence-based analysis of periodontally accelerated orthodontic and osteogenic techniques: a synthesis of scientific perspectives. Semin Orthod. 2008;14:305-16.

15. Frost HM. The regional acceleratory phenomenon: a review. Henry Ford Hosp Med J. 1983;31:3-9.

16. Baloul SS, Gerstenfeld LC, Morgan EF, Carvalho RS, Van Dyke TE, Kantarci A. Mechanism of action and morphologic changes in the alveolar bone in response to selective alveolar decortication-facilitated tooth movement. Am J Orthod Dentofacial Orthop. 2011;139:S83-101.

17. Alikhani M, Raptis M, Zoldan B, Sangsuwon C, Lee YB, Alyami B, Corpodian C, Barrera LM, Alansari S, Khoo E, Teixeira C. Effect of microosteoperforations on the rate of tooth movement. Am J Orthod Dentofacial Orthop. 2013;144:639-48.

18. Teixeira CC, Khoo E, Tran J, Chartres I, Liu Y, Thant LM, Khabensky I, Gart LP, Cisneros G, Alikhani M. Cytokine expression and accelerated tooth movement. J Dent Res. 2010;89:1135-41.

19. Kapoor P, Kharbanda OP, Monga N, Miglani R, Kapila S. Effect of orthodontic forces on cytokine and receptor levels in gingival crevicular fluid: a systematic review. Prog Orthod. 2014;15:65.

20. Fischer TJ. Orthodontic treatment acceleration with corticotomy-assisted exposure of palatally impacted canines. Angle Orthod. 2007:77:417-20.

21. Aboul-Ela SM, El-Beialy AR, El-Sayed KM, Selim EM, El-Mangoury NH, Mostafa YA. Miniscrew implant-supported maxillary canine retraction with and without corticotomy-facilitated orthodontics. Am J Orthod Dentofacial Orthop. 2011;139:252-9.

22. Al-Naoum F, Hajeer MY, Al-Jundi A. Does alveolar corticotomy accelerate orthodontic tooth movement when retracting upper canines? A split-mouth design randomized controlled trial. J Oral Maxillofac Surg. 2014;72:1880-9.

23. Hassan AH, Al-Fraidi AA, Al-Saeed SH. Corticotomy-assisted orthodontic treatment: review. Open Dent J. 2010;4:159-64.

24. AlGhamdi AST. Corticotomy facilitated orthodontics: review of a technique. The Saudi Dental Journal. 2010:22:1-5.

25. Kim SJ, Park YG, Kang SG. Effects of corticision on paradental remodeling in orthodontic tooth movement. Angle Orthod. 2009;79:284-91.

26. Dibart S, Sebaoun JD, Surmenian J. Piezocision: a minimally invasive, periodontally accelerated orthodontic tooth movement procedure. Compend Contin Educ Dent. 2009;30:342-4. 346, 348-50.

27. Sebaoun JD, Surmenian J, Dibart S. Accelerated orthodontic treatment with piezocision: a mini-invasive alternative to conventional corticotomies. Orthod Fr. 2011:82:311-9.

28. Keser El, Dibart S. Sequential piezocision: a novel approach to accelerated orthodontic treatment. Am J Orthod Dentofacial Orthop. 2013:144:879-89.

29. Alikhani M, Alansari S, Sangsuwon C, Alikhani M, Chou MY, Alyami B, Nervina JM, Teixeira CC. Micro-osteoperforations: minimally invasive accelerated tooth movement. Semin Orthod. 2015;21:162-9.

30. Salman LH, Ali FA. Acceleration of canine movement by laser assisted flapless corticotomy [an innovative approach in clinical orthodontics]. J Bagh College Dentistry. 2014;26:3

31. Savard B. Alveolar corticotomies by lasercision: a new procedure to accelerate orthodontic treatments. Int Mag laser Dent. 2014;6:16-21.
32. Higgins JPT, Green S. Cochrane Handbook for Systematic Reviews of Interventions Version 5.1.0 [updated March 2011]. The Cochrane Collaboration; 2011. www.cochrane-handbook.org. Accessed 19 Jan 2016.

33. Liberati A, Altman DG, Tetzlaff J, Mulrow C, Gotzsche PC, loannidis JPA, Clarke M, Devereaux PJ, Kleijnen J, Moher D. The PRISMA statement for reporting systematic reviews and meta-analyses of studies that evaluate healthcare interventions: explanation and elaboration. BMJ. 2009;339:b2700. doi:10.1136/bmj.b2700

34. Moher D, Liberati A, Tetzlaff J, Altman DG. Preferred reporting items for systematic reviews and meta-analyses: the PRISMA statement. Ann Intern Med. 2009;151:264-9.

35. Higgins JP, Altman DG, Cotzsche PC, Juni P, Moher D, Oxman AD, Savovic J, Schulz KF, Weeks L, Sterne JA. The Cochrane Collaboration's tool for assessing risk of bias in randomised trials. BMJ. 2011;343:5928.

36. Higgins JP, Thompson SG, Deeks JJ, Altman DG. Measuring inconsistency in meta-analyses. BMJ. 2003;327:557-60

37. Guyatt GH, Thorlund K, Oxman AD, Walter SD, Patrick D, Furukawa TA Johnston BC, Karanicolas P, Akl EA, Vist G, Kunz R, Brozek J, Kupper LL, Martin SL, Meerpohl JJ, Alonso-Coello P, Christensen R, Schunemann HJ. GRADE guidelines: 13. Preparing summary of findings tables and evidence profiles-continuous outcomes. J Clin Epidemiol. 2013;66:173-83.

38. Mehr R. Efficiency of piezotome-corticision assisted orthodontics in alleviating mandibular anterior crowding - a randomized controlled clinical trial [dissertation]. Connecticut (USA): University of Connecticut of Medicine and Dentistry; 2013. p. 1-61.

39. Leethanakul C, Kanokkulchai S, Pongpanich S, Leepong N, Charoemratrote C. Interseptal bone reduction on the rate of maxillary canine retraction. Angle Orthod. 2014;84:839-45.

40. Aksakalli S, Calik B, Kara B, Ezirganli S. Accelerated tooth movement with piezocision and its periodontal-transversal effects in patients with class I malocclusion. Angle Orthod. 2015;86:59-65.

\section{Submit your manuscript to a SpringerOpen ${ }^{\circ}$ journal and benefit from:}

- Convenient online submission

- Rigorous peer review

- Immediate publication on acceptance

- Open access: articles freely available online

- High visibility within the field

- Retaining the copyright to your article

Submit your next manuscript at $>$ springeropen.com 